\title{
Composite Type of Split Cord Malformation: Rare and Difficult to Explain
}

\author{
Yusuf Izci Cahit Kural \\ Department of Neurosurgery, Gulhane Military Medical Academy, Ankara, Turkey
}

To the Editor

The article by Singh et al. [1] entitled 'Long-term segment type 1 split cord malformation with two-level split cord malformation and a single dural sac at the lower split' aroused our interest when reading it. The authors report a case of two-level type 1 split cord malformation (SCM) with a low-lying conus at the L3-4 level. We congratulate the authors on presenting this rare clinical entity.

A composite type of SCM is very rare and only a few cases have been reported until today $[2,3]$. The frequency of composite-type SCM is lower than $1 \%$ in the literature [4]. We have also experienced one composite type of SCM and there was one-level type 2 SCM and two-level type 1 SCM in this patient. We removed all the splitting lesions in one session and released the spinal cord [5].

Despite the unified theory of embryogenesis proposed by Pang et al. [6], there still remains much confusion as to the classification of this malformation. One of the weak points of this theory is composite-type SCM. Although it has not been proven yet, the multiple accessory neuroenteric canal was considered to be responsible for the development of compositetype SCM [1-5]. However, there are two questions concerning this theory. Why does more than one neuroenteric canal develop during the embryogenesis? Why do different types of malformations occur at different levels? The multiple canal theory is not a reasonable and satisfactory enough option to explain the development of such a malformation. Although the cellular mechanisms responsible for such a theory are not fully known, experimentally induced perturbations of Hensen's node and the primitive streak during gastrulation have resulted in embryos with double axial structures in the experimental studies. However, there is no experimental study showing the presence of multiple neuroenteric canals. In short, the theory about the embryogenetic basis of this rare malformation has failed because it does not provide a satisfactory explanation for the development of composite-type SCM.

Dorsal bony septum is another weak point of accessory neuroenteric canal theory [7]. The incomplete regression of this canal cannot explain why the dura is partly separated by a bone spur, starting from the dorsal part of the spinal column. On the other hand, the dorsal tethering lesions such as dorsal bands or sinus tracts show similar characteristics of dorsal bony septum. Some post-natal embryonal cell populations may be the cause of bony or fibrous septums and therefore this rare malformation, but it is difficult to argue that a rudimentary canal is responsible for the development of dorsal bony septum.
Although much remains to be learned about SCM despite a lot that has been revealed about the SCM so far, further studies, we believe, will generate new information concerning the embryogenesis and pathophysiology of this malformation.

\section{References}

1 Singh PK, Khandelwal A, Singh A, Ailawadhi P, Gupta D, Mahapatra AK: Long-term segment type 1 split cord malformation with two-level split cord malformation and a single dural sac at the lower split. Pediatr Neurosurg 2011;47:227-229.

2 Ersahin Y: Composite type of split cord malformations. Childs Nerv Syst 2002;18:111.

3 Ersahin Y, Mutluer S, Kocaman S, Demirtas E: Split spinal cord malformations in children. J Neurosurg 1998;88:57-65.

4 Harwwod-Nash DC, McHugh K: Diastematomyelia in 172 children: the impact of modern neuroradiology. Pediatr Neurosurg $1990 ; 16: 247-251$.

5 Akay KM, Izci Y, Baysefer A, Timurkaynak E: Composite type of split cord malformation: two different types at three different levels. J Neurosurg 2005;102:436-438.

6 Pang D, Dias MS, Ahab-Barmada M: Split cord malformation. 1. A unified theory of embryogenesis for double spinal cord malformations. Neurosurgery 1992;31:451-480.

$\checkmark 7$ Akay KM, Izci Y, Baysefer A: Dorsal bony septum: a split cord malformation variant. Pediatr Neurosurg 2002;36:225-228.

\section{KARGER}

Fax +4161306 1234 E-Mail karger@karger.ch www.karger.com www.karger.com/pne
Yusuf Izci, MD

Department of Neurosurgery

Gulhane Military Medical Academy

TR-06018 Etlik, Ankara (Turkey)

Tel. +90 312304 5318, E-Mail yusufizci@yahoo.com 